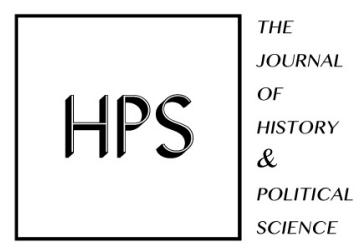

\title{
Caput Mundi: An Analysis of the Temple of Jupiter Optimus Maximus as a Case of Etruscan Influence on Roman Religious Architecture
}

\author{
HPS: The Journal of \\ History \& Political \\ Science \\ 2017, Vol. 5 1-12 \\ (C) The Author(s) 2017
}

\author{
Mario Concordia \\ York University, Canada
}

\begin{abstract}
While Roman architecture is often generalized as being primarily of Greek influence, there are important periods where other influences can be clearly identified. This paper considers the Etruscan, Greek, and Villanovan influence on Roman religious architecture through an examination of the Temple of Jupiter Optimus Maxmius, also known as the Capitolium, and argues that the temple is ultimately of primarily Etruscan influence.
\end{abstract}

\section{Introduction}

Religious temple architecture was a dynamic, evolving tradition throughout the entire span of Roman history. From its founding, customarily dated at $753 \mathrm{BCE}$ with the mythical tale of Romulus and Remus, until the eventual fall of the Western Empire in the $5^{\text {th }}$ century CE, temples were a central piece of the majesty of Roman architecture. But, like all construction fashion, what was dominant and popular in one period would inevitably change over time. As Becker indicates in his work, "Italic Architecture of the Earlier First Millennium BCE," many scholars believe that Roman temple architecture is completely indebted to Greek advancements and influence, and that historians should be looking at Classic Greek models when considering Roman architecture, ${ }^{1}$ but this is hardly a complete answer. While it is true that Rome began to steer toward a more Hellenistic aesthetic some time around the Late Republic to Early Empire Period, there is an entire period before that which cannot be understood in this simple way. This paper considers the Etruscan influence on Roman temple architecture throughout the period preceding Classic Greek influence on Rome. By 
examining the protohistoric and Early Monarchy periods of Rome and the neighbouring region of Etruria, it becomes apparent the extent of the Etruscan aesthetic influenced temple architecture in Rome, which culminated in the erection of Rome's venerable temple, the Capitolium. After a discussion addressing how scholars can reconstruct an accurate image of the temple, a comparative analysis of Etruscan and Greek temple forms shows how the Temple of Jupiter Optimus Maximus, which is often informally referred to as the Capitolium, exhibits uniquely Etruscan characteristics. Finally, by investigating the way the Capitolium impacted the rest of the republic, the Etruscan influence on Rome's temple building culture, as a whole, is revealed.

Understanding the evolution of Roman temple architecture is not only important in helping scholars understand the mentality and social dynamics at play within the once great empire, but a better understanding of these underlying influences allows scholars to more accurately extrapolate and predict what these lost monuments would have looked like, which makes inquires into these matters necessary. By examining the case of the Temple of Jupiter Optimus Maximus, including its conception, construction and effect, it is shown that Roman religious architecture was under immense Etruscan influence, from the founding of Rome until, at least, the Middle to Late Republic.

\section{Protohistory of Rome and the Construction of the Capitolium}

Through analyzing the state of the religious architectural tradition and technology, both in the area of Rome and in the neighbouring region of Etruria, from the Late Iron Age through to the construction of the Capitolium, at the end of the Roman monarchy, historians gain some insight into the extent Etruscan influence affected early Roman temple design. As Boethius and Ward-Perkins argue in Etruscan and Roman Architecture, most of the Indigenous people of the Latium region likely lived in simple huts. ${ }^{2}$ This lifestyle continued until around the eighth century BCE, when evidence begins to appear of a slightly more advanced culture. ${ }^{3}$ This Late Iron Age culture, between $10^{\text {th }}$ and $8^{\text {th }}$ century BCE, was referred to as Villanovan after an early archaeological excavation site. While this Villanovan culture had only learned rudimentary building techniques, and by most accounts did not seem to have passed down a great deal of traditions and technologies to their descendants, to dismiss them out of hand would be in error. It is important to note that the name Villanovan is a modern convention that demonstrates our lack of ability to identify which, if any, Italic cultural groups these remains belong to. Boethius and Ward-Perkins identify some similarities between Villanovan building practices with those found in later Rome, but dismiss them as insignificant. This view is challenged by works of later historians, such as Becker, who argues the development and popularity of atria in ancient Rome, for example, were an aesthetic of Villanovan origin. ${ }^{4}$ Further, as Becker points out, many of those Villanovan sites formed the basis of the more complex settlements that followed. ${ }^{5}$ One perfect example of this is the Late Iron Age foundations found on the Palatine Hill, which must have formed part of Roma Quadrata in the protohistory of Rome. If Villanovan settlements had not set these foundations, later cities would not have been as successful and perhaps would not have existed at all. Roman religious architecture is at least partially 
indebted to the Indigenous Villanovan culture and therefore cannot be dismissed as wholly Greek, Etruscan, or otherwise.

Etruscan influence can be seen in Roman temple architecture, from the protohistory of Rome up to and including the construction of the Temple of Jupiter Optimus Maximus. After considering the contribution of other indigenous building techniques on Roman temple architecture, it is important to look at the larger, more specific, Etruscan influence on the building tradition leading up to the construction of the Capitolium, considered the largest known Etruscan-style temple. ${ }^{6}$ As the Etruscan civilization developed an important mining industry specializing in iron, a material that was in great demand by the developing Hellenic world, including the Greek colonies of Magna Graecia, they began to accrue a significant amount of wealth. That wealth spilt over into cultural works and regional recognition, and there was a great explosion of Etruscan culture thought the Italian region around the seventh century BCE. It was during this period, which correlates with the middle of the Roman monarchy, that Rome elected its first Etruscan king. As Livy tells us in The History of Rome, Lucius Tarquinius Priscus commanded the building of the temple, and during its construction, "whilst they were digging the foundations of the temple, a human head came to light with a perfect face; this appearance unmistakably portended that the spot would be the stronghold of the empire and the head of all of the world." 8 This, in fact, is how Capitoline Hill acquired its name, as caput is Latin for head, leading Romans to often refer to the hill as the caput mundi, the head of the world. The significance of an Etruscan king building this great Roman temple cannot be understated. Tarquinius Priscus would have employed many engineers and artists from Etruria in the construction of the temple, and Etruscan design elements would be inevitable, if not intentional. Further leaving the mark of the Etruscan influence is the fact that Tarquinius Priscus, in an attempt to highlight the supremacy of his new temple and its associated cult, allegedly destroyed other temples on the hill that were erected earlier, those that were attributed to the potentially mythical King Tatius. ${ }^{9}$ Although the Capitolium was clearly connected to Etruscan architectural techniques, the Romans were not necessarily indebted to the Etruscans themselves. In fact, there is a long history of war between these two groups, especially while Rome was under the rule of the three Etruscan kings, and as Stamper argues, the Capitolium would have been constructed, in part, from spoils won in Rome's victories of the Etruscans themselves, the Temple of Veii being one example. ${ }^{10}$ This would mark the beginning of a long tradition in which Rome took culturally from those it conquered, and integrated elements they liked into their own aesthetic. While it is important to note that by analysing accounts of Rome's early history it is evident the temple building tradition probably had some influence from the local Villanovan culture, we must acknowledge a far greater amount of Etruscan influence went into the construction of temples like the Capitolium, and its successive temples.

\section{Reimagining the Temple of Jupiter Optimus Maximus}

Through a comparative analysis of Etruscan, Greek, and Indigenous elements that constituted the components of the Temple of Jupiter Optimus Maximus, the extent of Etruscan influence on Roman temple architecture becomes apparent. To understand just 
which aesthetic styles were at work at the Temple of Jupiter Optimus Maximus, historians first need to come to a consensus as to what the temple looked like, which can actually be quite difficult. Further complicating the matter is the fact that the temple had to be rebuilt a number of times due to suffering numerous fires, so the matter of placing arguments in chronological context becomes of paramount importance. To battle these issues, historians have numerous tools at their disposal for reconstructing ancient buildings; some of these include using evidence of an archaeological, literary, epigraphic, artistic, or numismatic nature. The lack of archaeological evidence was the cause of much speculation on the history of the Capitolium, and scholars, especially of the Renaissance, struggled to agree on what conclusions to draw. It was not until new excavations in the late nineteenth century that solid archaeological evidence started to come to light. ${ }^{11}$ Still, the new archaeological evidence, in the case of the Capitolium, only gives historians an understanding of the substructure of the temple. While this provides a very basic understanding of what the temple may have looked like, there have been many suggested lay-outs submitted over the years that do not conflict with the foundation. ${ }^{12}$ This type of logically contradiction is precisely the reason why historians are compelled to search other types of sources for more evidence. This shows us that sometimes-sparse archaeological evidence is difficult to rely on and can lead to many extrapolated theories from the same evidence. That being said, when reliable data is collected and compiled, archaeological evidence can become an important element of history.

Academics often have to rely on the works of ancient historians, and other authors, to help us understand the context and construction of destroyed temples and other buildings, when little archaeological evidence remains. In the case of the Capitolium, which only has significant portions of foundation left, scholars are left to extract the thought process and technical methods that went into these buildings, through ancient written accounts. Some of the most important references in this case are Livy's work, Ab Urbe Condita, and Vitruvius's architectural treatise, De Architectura. From these two ancient sources much of the history and appearance of the Temple of Jupiter of Optimus Maximus can be understood. From Livy, we learn important historical context, such as who constructed the temple and for what purpose: "Here [Tarquinius'] first concern was to build a temple of Jupiter on the Tarpeian mount to stand as a memorial of his reign and of his name testifying that of the two Tarquinii, both kings, the father had made the vow and the son had fulfilled it." ${ }^{13}$ Clearly, if Livy is to be believed, we see the connection to Etruria in relation to the construction of the temple, as it was built in the Etruscan period of the monarchy, which reinforces the evidence established in the previous section. Other, more technical sources, like Vitruvius, mention the temple almost dismissively, lumping it in as a building furnished in the Etruscan style, without giving much thought to the inherent complex dynamic; but, in other places, Vitruvius gives us much more information of what an Etruscan Temple looks like. ${ }^{14}$ While these accounts help us form some ideas of what these types of monuments may have looked like, and how they came into existence, we cannot overlook that these sources, too, are fraught with problems. For instance, both of these works were written during the reign of Augustus, placing them approximately five hundred years after the fact. We cannot simply presume that they would have had some unfettered access to solid source material themselves, as these authors, themselves are among the fathers of history, and more likely they were recording a blend of some sparse documents, and a great deal of oral tradition. Further, these authors must have had, at least, some concern for the reputation of Augustus, 
and were writing, in part, to glorify his reign. In fact, relying on the written evidence alone, led seventeenth century academics to argue the temple was located in an entirely different position on the hill, possibly perpetuating their own political motivations, which shows historians the dangers of relying on just one type of evidence. ${ }^{15}$ Regardless of these challenges, written sources are an important tool in helping historians reconstruct lost buildings.

Historians must also look to the ancient artistic representation of monuments when hoping to envision what those monuments potentially looked like. Perhaps the most useful tool when trying to envision a destroyed monument is an iconographic representation contemporary to the buildings existence. In the case of the Capitolium, it was a building of central importance to Roman culture, and that gives us the good fortune of being able to study its representation on coins. As mentioned before, the temple had to be rebuilt multiple times due to fires and this makes the coinage especially interesting, as we can see how the temple changed as time progressed. Importantly, in Figure 2, we see the temple already is represented with six columns in front and three cellae between them, at the start of the period of Augustus, and its overall design corresponds with Vitruvius' account of the temple ${ }^{16}$ (Fig. 2). In Figure 1, we see how the temple probably looked after restorations were conducted by

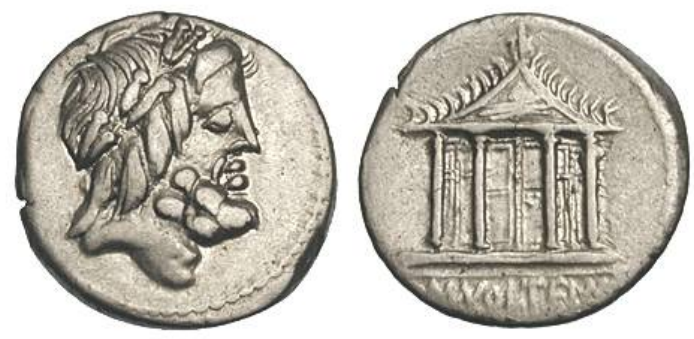

Fig. 1. M. Volteius M.F. $78 B^{17}$
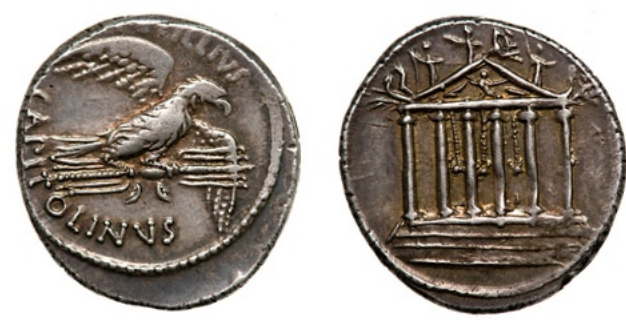

Fig. 2.

Petillius Capitolinus AR Denarius. $43 B^{18}$

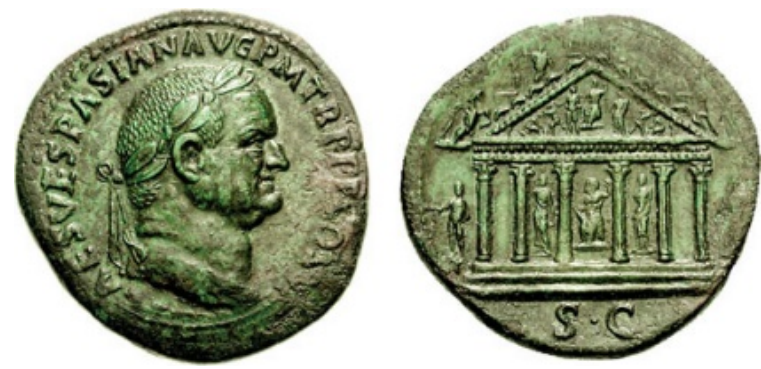

Fig. 3

Vespasian $A E$ Sestertius. $76 A D^{19}$

Sulla in $83 \mathrm{BC}^{21}$ (Fig. 1). Figure 3 shows the temple after even more repairs under Vespasian. (Fig. 3) Contemporary depictions, as all forms of evidence, are not without their own problems. Even in these representations, historians face issues with scaling, and the importance artists might have lent to these images symbolically may have distorted how much reality is represented and these representations often present more questions than the answer. For example, Figure 1 only presents the temple with 4 columns and with the doors closed, which was traditionally only occurred during times of peace, leading us to question 
whether this is actually a depiction on the Capitolium at Rome, or perhaps one of the Capitolia elsewhere in the empire. The podia of all three images are different and historians should ask if this was perhaps caused by a change in technological capacity or perhaps a perceived decline in the importance of the podium. Lastly, in Figure 3, we see a clear representation of the traditional Capitolium Triad in between the columns but what of the figure standing outside of the temple? Was this meant to represent another statute, or person, perhaps an image of Vespasian, himself, presenting the temple back to Rome? Although these questions are outside the scope of this paper, they do serve to highlight the difficulties in working with iconographic representations of monuments.

The fact that all sources have their flaws is perhaps the most important element to take into consideration. These tools often do not provide sufficient evidence on their own in most cases, but through a combination of techniques and approaches, when evidence corroborates other evidence and fact is sifted out from fiction, we begin to form an image that might come close to the reality. By combining these techniques of archaeological evidence, ancient written sources, and contemporary representations, historians can reconstruct an image of the Temple of Jupitar Optimus Maximus, which in turn allows us to discuss what sort of architectural and cultural influences might have been applied to it.

\section{Etruscan, Greek and Indigenous Influences in the Capitolium}

By comparing the Etruscan components of the temple of Jupiter Optimus Maximus to Greek architectural forms, the greater Etruscan influence becomes strikingly evident. Once a basic representation of the Capitolium has been established, a comparative analysis becomes possible. The first point of distinction from Greek temples, in this case, is the matter of the temple's columns. The style of column deployment in the Capitolium can be called peripteros sine postico, which can be described as columns encircling the temple with the exception of the rear wall or section. As Hopkins points out, this formation of columns is not specifically described by Vitruvius in his work, ${ }^{22}$ but Vitruvius does provide us with adequate vocabulary to describe this set up. The sine postico layout is used extensively in Etruscan temple construction ${ }^{23}$ this layout gives the temple an obvious front and back, which was important in the ritual practice of the Romans and Etruscans. In contrast to Greek practices which were conducted encircling their temples, Romans and Etruscans placed significance in the temples' facing. Vitruvius also describes the Capitolium as having been constructed in araeostyle ${ }^{24}$ which he describes as having a spacing of 4 or more of the columns diameters, which was more common in Etruscan temples. (Fig. 4) The reason for this is that araeostyle column spacing is only possible with a temple epistyle that was at least partially wooden, otherwise the temple would collapse due to excessive weight on each span. While there was a time in Ancient Greece's dark period, between the fall of Mycenae and the sixth century $\mathrm{BCE}$ where the Greeks did build their temples from wood, by the global re-emergence of Greece in the sixth century, they had returned to constructing their temples wholly out of stone and marble. ${ }^{25}$ This peculiarity of partially wooden construction is an important distinction between Etruscan and Greek temple architecture ${ }^{26}$ and helps to cement the Capitolium as being more influenced by Etruscan culture. By analysing the columns of the Capitolium we see the greater influence of Etruscan temple architecture. 


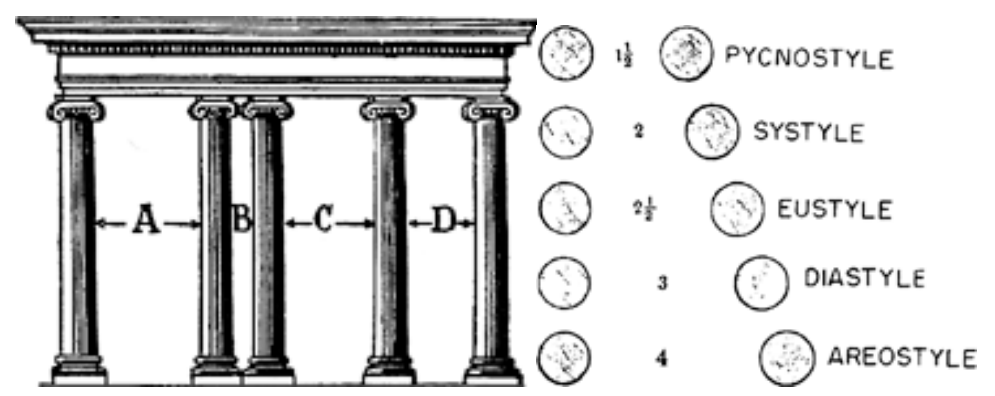

Fig. 4

\section{Examples of intercolumniation. A: areostyle; B: coupled columns; C: diastyle; D: eustyle ${ }^{27}$}

Considering the podium and frontal stairs of the Capitolium, we can discern its Etruscan influence. Another distinguishing Etruscan feature of the Capitolium is its use of a podium and frontal staircases, which is in contrast to traditional Greek temple architecture. In The Architecture of Roman Temples, John W. Stamper presents a modern re-envisioning of the Capitolium (Fig 5.), which includes the use of multiple podiums to achieve its greater height. What is agreed upon by historians is that the Capitolium did make use of at least one podium, which is a shared commonality with other Etruscan temple architecture. Although there are exceptions to podium use in Etruscan temples, such as the temples at Volsinii, those are due to the incorporation of podium substitutes that were naturally occurring in the area, like a rock outcropping or hill. ${ }^{28}$ Additionally, the placement of stairs only in the front section of the temple, as compared to multiple staircases on different facings, as in the case

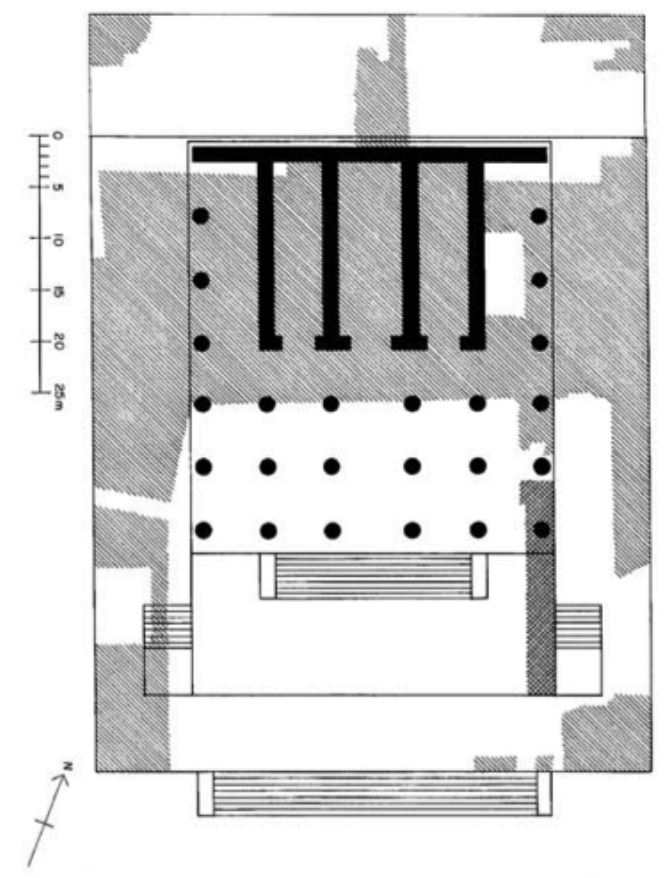

Fig.5

Stamper's proposed Capitolium with multiple podia ${ }^{29}$ 


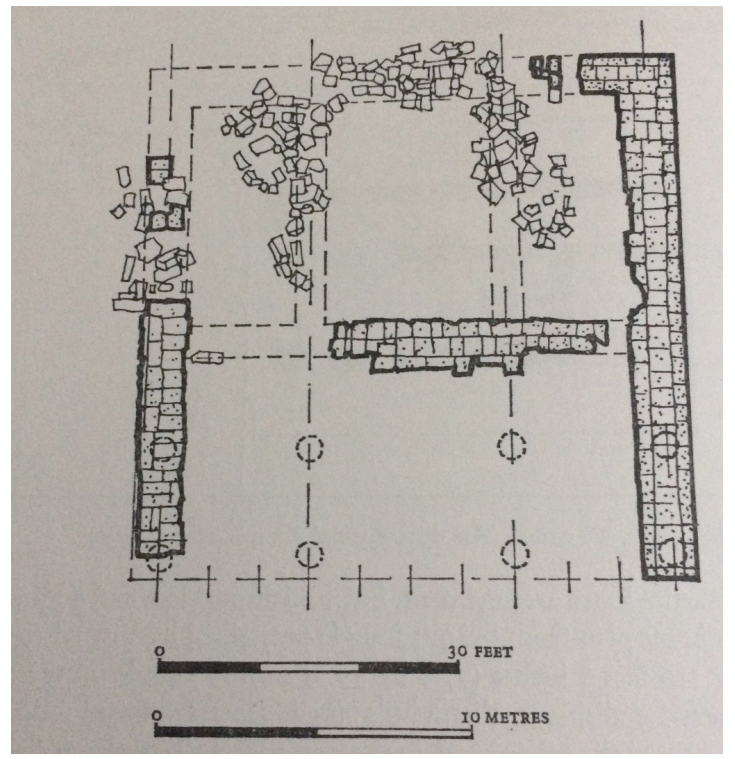

Fig. 6

Portonaccio temple at Veii. Early Estrucan temple; no directional facing included in origina ${ }^{30}$

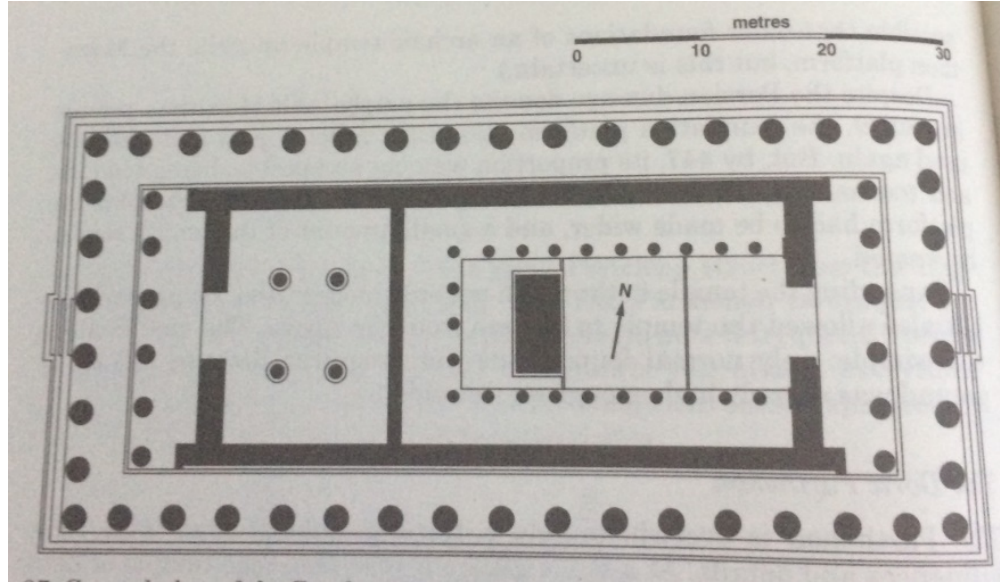

Fig. 7

Plan of the Greek Parthenon, showing absence of facing among other Greek attributes ${ }^{31}$

of the Parthenon (Fig. 7), or lack of stairs altogether in other Greek temples, is another Etruscan trait. As previously mentioned, this distinction goes beyond a simple architectural one, and translates into important differences in the religious practices of the Greek and Roman traditions, showing historians that not only do these temples look different, but they are used differently as well. ${ }^{32}$ By inspecting the podia and stair placement in the Temple of Jupiter Optimus Maximus, we see that it relies more heavily on Etruscan traditions than Greek ones.

Considering the cella of the Capitolium shows historians the Etruscan influence in the heart of the temple. Perhaps one of the most distinguishing features of the Capitolium, which extends from its Etruscan roots, is the inclusion of a tripartite cella. This tradition of 
threes is an important aspect of Etruscan culture, and forms the basis for the triad association. In Etruscan and Roman Architecture, authors Axel Boethius and J. B. WardPerkins state, "The late compilers of Etruscan tradition report that the founders of the Etruscan towns thought that every proper town ought to have three gates, three main roads, three temples (Those of Tinia, Uni, and Minvra, i.e. Jupiter, Juno, and Minerva)". ${ }^{33}$ Boethius and Ward-Perkins provide this link to the Capitoline triad, which is a pretty striking distinction between Greek and Etruscan Temples. The formation of tripartite cellae began to emerge in early Etruscan temples, the Portonaccio Temple at Veii being one such example (Fig. 6). Stamper also notes that Jupiter's association with Juno and Minerva in the Capitolium came out of this translated tradition of the Etruscans. ${ }^{34}$ The Capitoline Triad, as it would come to be known, would become one of the most important cults of Roman religion, and its establishment and arrangement can be traced back to an earlier Etruscan model. If the Capitolium only showed one or two points of similarity with Etruscan temple architecture, the argument that Greek influence played a more important role in Roman temple design during the late monarchy through to the Late Republic might seem a little more substantial. By analysing the specific components of the Temple of Jupiter Optimus Maximus, such as the columns, podia, stairs and cellae, we see that the Capitolium and its subsequent effects on Roman temple design are indebted to Etruscan roots.

\section{The Effects of the Capitolium on the Roman Republic}

By considering the effects of the Capitolium on the rest of the Roman Republic, and Roman temple architecture in general, we can see that Rome was affected by Etruscan influence throughout the Early to Mid-Republic Period. Due to its founding connection to Jupiter and the triad, the Capitolium became a very important monument for Rome. ${ }^{35}$ The spread of similar temples exploded throughout the Republic ${ }^{36}$ and subsequent Roman cities would create their own Capitolia in an effort to emulate and appease Rome, itself. ${ }^{37}$ The Etruscan influence in the Temple of Jupiter Optimus Maximus is very clear, and, as the Capitolia spread throughout the republic, an inevitable transfusion of the culture of Etruscan temple architecture occurred. While there was a distinct turn toward Greek building practices after the Etruscan period, the transitionary period beginning around the second century BCE. ${ }^{38}$ and reconstruction on monuments such as the Capitolium became more Hellenistic as later consuls and emperors had the opportunity to rebuild them, ${ }^{39}$ the Temple of Jupiter Optimus Maximus, and the worship of the Capitoline triad, remained an important aspect of Rome throughout her history, with priests remaining dedicated to the observance of its rituals. ${ }^{40} \mathrm{In}$ fact, the Temple of Mars Ultor in the Forum of Augustus, included many aspects and traditions of the Capitolium, showing the Etruscan influence even outside of tripartite cella temples. ${ }^{41}$ Through an analysis of the extent the Capitolium impacted the Roman temple building tradition, scholars can see the way in which Etruscan architecture proliferated through the Roman Republic. 


\section{Conclusions}

After a thorough exploration of the protohistory and Monarchy periods of Rome and Etruria, followed by an analysis of the Capitolium, including its re-envisioning, and a comparative analysis of its components and its impact throughout the republic, it is apparent that Roman religious' architecture was under significant Etruscan influence from the founding of Rome until the middle republic. By considering Roman protohistory, sources reveal attributes that reflect indigenous Italic traditions, specifically Etruscan influences, that culminates in the construction of the Capitolium. While exploring the Capitolium itself, we see the difficulty that historians face in reconstructing these monuments, and witnessed some of the pitfalls that corrupted earlier images of the temple. Analysis of the various components of the Temple of Jupiter Optimus Maximus displays a distinct Etruscan, over Greek, tradition. Finally, by looking at the successor temples, including the other Capitolia under Roman domain, this Etruscan influence can be seen as resonating throughout the Republic. As the Republic marched on toward the Empire, it

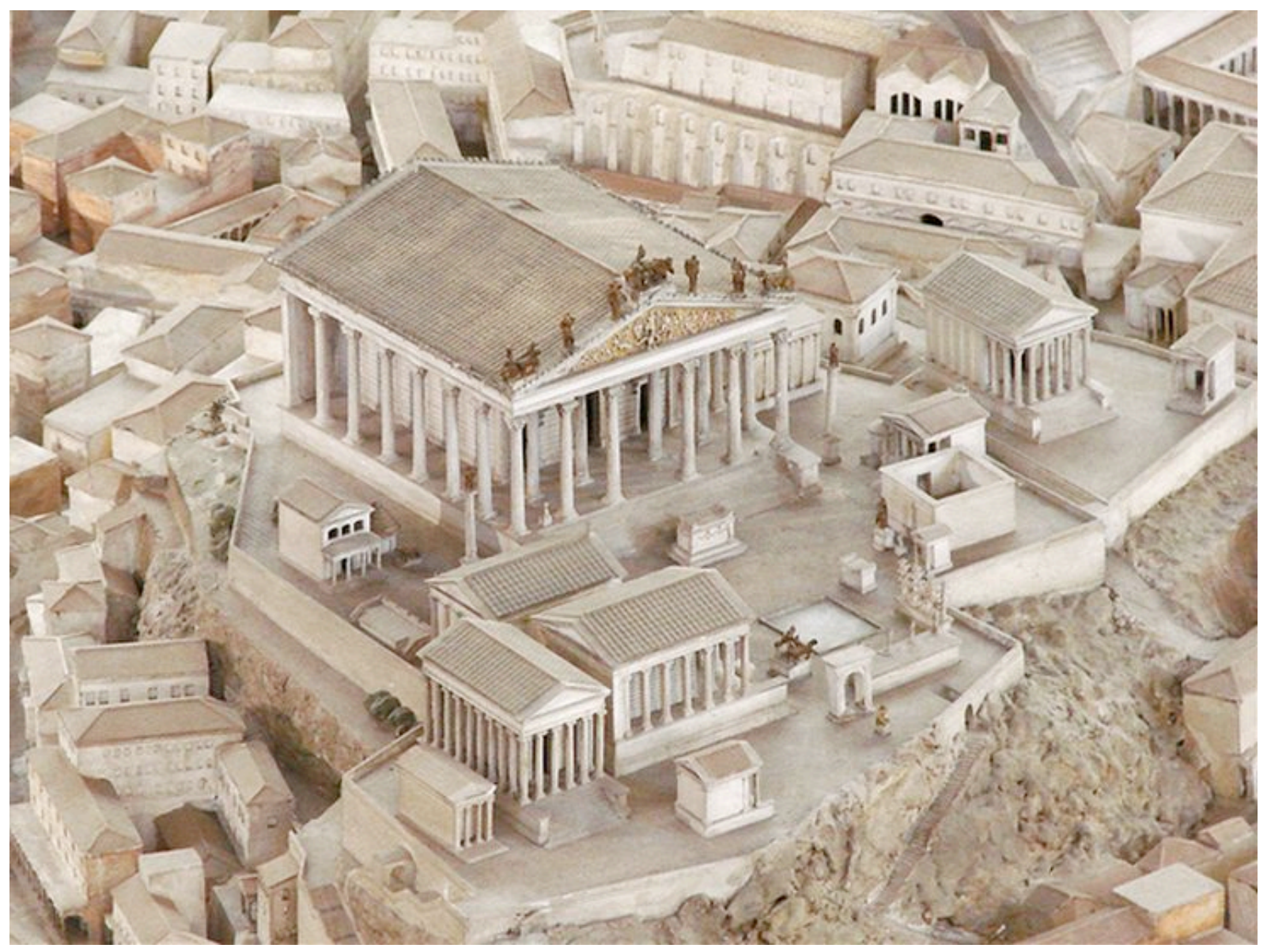

Fig. 8

A portion of Italo Gismondi's "Il Plastico Della Roma Antica," a scale imagining of the Capitolium around the time of Constantine I, built at a 1:250 scale ${ }^{42}$ 
becomes clear that the fashionable Etruscan aesthetic began to fade. As early as the second century BCE, we see the general trend to move toward more Classic Greek forms. ${ }^{43}$ But historians often miss a critical point about both the Greek and Etruscan influences on Roman Architecture. Rome's ability to integrate these various styles and cultures into its own is part of what generates the Roman distinction. Simply because Roman architecture draws influences from other cultures does not make it any less Roman. No more should we dismiss buildings like the U.S. Capitol as being Roman because it draws heavily from Roman inspiration. Further, we could not dismiss all North American architecture and culture as being derivative of England and France, despite multiple buildings being erected in the period before both American and Canadian confederation. The Roman Capitolium was an incredible architectural achievement, which survived all three phases of Roman constitution, the monarchy, republic, and empire, and its spirit survives, even today.

\section{NOTES}

${ }^{1}$ Jeffrey A. Becker, "Italic Architecture of the Earlier First Millennium BCE," in A Companion to Roman Architecture. (New Jersey: John Wiley \& Sons, 2014), 13.

${ }^{2}$ Axel Boethius and J. B. Ward-Perkins, Etruscan and Roman Architecture (Harmondsworth: Penguin, 1970), 3-5.

${ }^{3}$ Boethius, Etruscan and Roman Architecture, 13.

${ }^{4}$ Becker, "Italic Architecture," 14.

${ }^{5}$ Ibid., 8.

${ }^{6}$ Boethius, Etruscan and Roman Architecture, 42.

${ }^{7}$ Ibid., 4.

${ }^{8}$ Livy, History of Rome, trans. Rev. Canon Roberts, ed. Ernest Rhys (London: J. M. Dent \& Sons, London, 1905, 1905. Everyman's Library, Perseus Digital Library. Tufts University), Accessed May 31, 2016, http://www.perseus.tufts.edu, 1.55.5.

${ }^{9}$ John W. Stamper, The Architecture of Roman Temples: The Republic to the Middle Empire (Cambridge, U.K.: Cambridge University Press, 2005), 11.

${ }^{10}$ Ibid., 12.

${ }^{11}$ Ibid., 18.

${ }^{12}$ John N. Hopkins, "The Capitoline Temple and the Effects if Monumentality on Roman Temple Design," in Monumentality in Etruscan and Early Roman Architecture: Ideology and Innovation (Austin, Texas: University of Texas Press, 2012), 112.

${ }^{13}$ Livy, History of Rome, 1.55.1.

${ }^{14}$ Vitruvius Pollio, Ingrid D. Rowland, Thomas Noble Howe, and Michael Dewar. Vitruvius: Ten Books on Architecture (New York: Cambridge University Press, 1999), 49.

${ }^{15}$ Stamper, The Architecture of Roman Temples, 18.

${ }^{16}$ Vitruvius, Vitruvius, 60-61.

17 "Coin Detail - Coinproject.com." Coin Detail - Coinproject.com. Accessed May 31, 2016. http://www.coinproject.com/coin_detail.php?coin=3900

18 "Coin Detail - Coinproject.com." Coin Detail - Coinproject.com. Accessed May 31, 2016. http://www.coinproject.com/coin_detail.php?coin=286493 
19 "Vespasian, Roman Imperial Coins Of, at WildWinds.com." WildWinds.com. Accessed May 31, 2016, http://www.wildwinds.com/coins/ric/vespasian/i.html

${ }^{21}$ Stamper, The Architecture of Roman Temples, 14.

${ }^{22}$ Hopkins, "The Capitoline Temple and the Effects of Monumentality on Roman Temple Design," 125.

${ }^{23}$ Boethius, Etruscan and Roman Architecture, 31.

${ }^{24}$ Vitruvius, Vitruvius, 49.

${ }^{25}$ Mary Emerson, Greek Sanctuaries: An Introduction (London: Bristol Classical Press, 2007), 8.

${ }^{26}$ Boethius, Etruscan and Roman Architecture, 31.

${ }^{27}$ Images provided by http://encyclopedia2.thefreedictionary.com/araeostyle.

${ }^{28}$ Boethius, Etruscan and Roman Architecture, 31.

${ }^{29}$ Stamper, The Architecture of Roman Temples, 28.

${ }^{30}$ Boethius, Etruscan and Roman Architecture, 36.

${ }^{31}$ Emerson, Greek Sanctuaries: An Introduction, 84.

${ }^{32}$ Hopkins, "The Capitoline Temple and the Effects of Monumentality on Roman Temple Design," 123.

${ }^{33}$ Boethius, Etruscan and Roman Architecture, 29.

${ }^{34}$ Stamper, The Architecture of Roman Temples, 13.

${ }^{35}$ Ibid., 1.

${ }^{36}$ Hopkins, "The Capitoline Temple and the Effects of Monumentality on Roman Temple Design," 124-125.

${ }^{37}$ Stamper, The Architecture of Roman Temples, 3.

${ }^{38}$ Becker, "Italic Architecture," 3.

${ }^{39}$ Stamper, The Architecture of Roman Temples, 14.

${ }^{40}$ Ibid., 13.

${ }^{41}$ Ibid., 2.

42 "Tour XII - Walking Tours of Ancient Rome." Tour XII - Walking Tours of Ancient Rome. Accessed May 31, 2016. http://mercuryguides.com/images/TourI/optimus.jpg

${ }^{43}$ Becker, "Italic Architecture," 3. 